\title{
[AUtOR]RETRATo Coletivo: ANDROMAQUia ON-LINE \\ NA [DES]CONSTRUÇÃO DE UMA IDENTIDADE COLETIVA
}

\section{Nardo Germano}

Doutorando em Poéticas Visuais e integrante do Grupo de Pesquisa Poéticas Digitais (ECA-USP). Artista multimídia, poeta e fotógrafo, mestre em Artes pela ECA-USP e bacharel em Letras pela FFLCH-USP

\section{Resumo}

Este artigo discorre sobre os processos de construção identitária nos mass-media e sua [des]construção na obra interativa Andromaquia on-line (2004), integrante do núcleo digital da série artística Auto-retrato coletivo (1987-), organizada como um repositório crítico das representações marcadas por estigmas sociais. A abertura poética da obra aos espectadores propõe dialogismo e polifonia, absorvendo alteridade, expressões e pontos de vista com o envio de contribuições heteróclitas dos interatores (textos, desenhos e símbolos), problematizando a identidade coletiva, através de formulário de opinião, à semelhança do fenômeno hoje em voga nas páginas de jornais e revistas on-line. Ancorado no conceito de auteur en collectif de Weissberg, proponho a noção de poétiques en collectif: poéticas em coletividade como procedimento de apropriação artística e tecnopolítica dos mecanismos de produção das representações da realidade

\section{Palavras-chave}

interatividade, autoria, dialogismo/polifonia, auteur en collectif, poéticas em coletividade.

\section{Abstract}

This article discusses the processes of identity construction in mass-media and its [de]construction in Andromaquia on-line (2004), an interactive artwork from the digital core of my artistic serie titled Collective Self-Portrait (1987-) which is organized as a critical repository of representations marked by social stigmata. The poetic openess of the work proposes dialogism and polyphony, absorbing alterity, expressions and points of view when the interactor sends heteroclite contributions (texts, drawings and symbols) and problematizes the collective identity, through a webform like the phenomenon of the newspapers and magazines online. Anchored in Weissberg concept of auteur en collectif, I propose the concept of poétiques en collectif: poetics in collectivity as a procedure of artistic and technopolitical appropriation of the production mechanisms of the reality representations.

\section{Key-words}

interactivity, authorship, dialogism/polyphony, auteur en collectif, poetics in collectivity. 


\section{Identidade e identificação}

O presente artigo discorre sobre os processos de construção identitária desenvolvidos nos mass-media e analisa a forma como sua [des]construção é instaurada em Andromaquia on-line (2004), obra interativa integrante do núcleo digital de minha série artística Auto-Retrato Coletivo (1987-). A série compõe-se originalmente de um conjunto de autorretratos sem negativo, obtidos em cabine Fotomática para fotos de documentos. Discutindo a questão da construção identitária marcada por estigmas sociais, expandiu-se para a constituição de autorretratos híbridos entre o Indivíduo e o Coletivo, finalmente organizando-se artisticamente como repositório crítico de uma identidade coletiva.

Nos ensaios fotográficos Auto-objeto e sujeitos, obras inaugurais da série em 1987 (1), reconheci na cabine de fotos para documentos da Fotomática um instrumento para obtenção de autorretratos ao perceber que, por ser um estúdio automático, o usuário reproduz toda a mise-en-scène característica do ato de autorretratar-se quando posa para o registro sem o auxílio externo de um operator (2) (BARTHES, 1981: 23), ou seja, de um fotógrafo por trás da objetiva. Nesses ensaios, o tema da identidade no autorretrato coloca-se numa perspectiva crítica, haja vista que "produto da mesma lógica indiciária, o retrato de identidade herda do retrato policial uma série de características" (FABRIS, 2004: 50), explicitando-se nas obras a problemática da elaboração da identidade em registros indiciários.

Em Auto-objeto, minha identidade individual (que até então predominava em meus autorretratos), expande-se com a transferência da criação no espaço íntimo do estúdio fotográfico para a cabine Fotomática situada em espaço público, com uma função diretamente ligada à identificação social. Por via dessa mudança de perspectivas, usos e funções, bem como da apropriação massiva dessas imagens ready-made como autorretratos, o ensaio desenvolveu-se numa vertente nitidamente preocupada com a relação Indivíduo/Coletivo e suas formas de representação.

Nesse contexto em que "a identidade transforma-se (...) em identificação, num processo de recenseamento social ao qual todos se devem sujeitar para ganhar um atestado de existência" (FABRIS, 2004: 50-51), configurou-se o ensaio de um autorretrato como cidadão, como indivíduo interpretado pelo viés social que, num jogo metonímico, representa a coletividade. Instaurou-se nesse momento de minha produção de autorretratos a noção de identidade coletiva associada ao caráter censitário como "uma espécie de autorretrato coletivo que serve para reforçar a identidade nacional” (STARR, 1983: 19, tradução minha), cuja expressão, num movimento de ironia e estranhamento, culminou na denominação da própria série de ensaios fotográficos: "Num dado momento submeto meu rosto: objeto fotográfico. Outros seres, através de mim, encontram expressão. Sua redundância multiplica-me. E me transforma em todos: Identidade Coletiva. Auto-Retrato 
Coletivo" (GERMANO, [1987] 2007: 185).

Obtido no contexto do mercado capitalista, o retrato de documento da Fotomática constituiu-se para mim numa "mercadoria passível de ser eleita como emblema de uma dada situação, real ou fictícia" (CHIARELLI, 2001), que, ao ser apropriada como explicitação do apagamento da identidade com ênfase social (3) (CHIARELLI, 1999: 132-137), configurou-se numa alegoria do coletivo, na mímese de uma tipologia de brasileiros estruturada como retrato compósito (4) de forma a revelar dialeticamente a sua inviabilidade. Nesse sentido, a obra procura também esvaziar as implicações históricas que relacionam a fotografia automática de documentos com a fotografia criminal indiciária, da qual descende (FABRIS, 2004: 40-50) e cujo estigma é tão bem explicitado por Barthes, quando declara que "nada como uma foto 'objetiva', do tipo 'Fotomática', para fazer de você um bandido, procurado pela polícia" (1980: 27, tradução minha), denotando aqui o quanto é difícil escapar das amarras da História. Auto-objeto propõe assim a possibilidade de um novo devir histórico para a cabine, libertando-a de seu passado, lembrando que "a arte é um meio de experimentar o devir do objeto" como propõe Cklovski (apud TOLEDO, 1973: 45), na perspectiva de não reproduzir o status quo, mas inová-lo/renová-lo, explorando novas funções não apenas práticas ou utilitárias, mas também estéticas e ideológicas.

O ensaio Sujeitos amplia o leque da representação social circunscrito por Auto-objeto com a inserção de meus alter-egos masculino e feminino, incorporados respectivamente por meu irmão gêmeo Agnus Valente e pela atriz Zilma Barros que, sob minha direção, posam para a captura de autorretratos com os torsos nus dentro da cabine Fotomática e constituem uma alteridade mais efetiva no corpusda série. Retirados os rostos das imagens, o ensaio é composto por um conjunto de colagens de autorretratos acéfalos com recortes de notícias, fotos e manchetes de jornal oriundos das páginas do diário Notícias Populares (em circulação na época), numa apropriação crítica do repertório e dos discursos flagrados nos mass-media pelo tratamento conferido aos fait-divers

Explicitando não somente o apagamento da identidade, a obra assume um tom de denúncia ao conferir visibilidade a um processo de construção ficcional de uma identidade popular "enquanto categoria potencialmente desviante", como "protagonista da ilegalidade" (SERRA, 1980: 20-21), sob a égide do crime e da violência que domina não apenas as notícias do cotidiano, mas se reitera até na página de horóscopos, sob o princípio de uma suposta irracionalidade e predisposição das camadas populares à violência. A problematização dos meios de comunicação de massa no processo de construção identitária coloca-se na obra com o meticuloso enquadramento de fragmentos de textos e imagens, buscando esvaziar ou conturbar as mensagens do material de origem. Esse procedimento de distanciamento crítico na feitura das colagens corresponde a um desmonte de um aparelho ideológico de Estado - o aparelho de informação que, ao embutir “através da imprensa, da rádio, da televisão, em todos os 'cidadãos', doses quotidianas de nacionalismo, 
chauvinismo, liberalismo, moralismo" (ALTHUSSER, 1980: 63), promove cotidianamente a construção de uma falsa consciência do cidadão sobre si mesmo.

O sensacionalismo, deslocado de seu contexto "jornalístico" original, desmascara-se, pelo contraponto com as figuras de torsos desnudos nas fotos de documento. Propondo-se a redimensionar os sentidos, repudiando o sadismo, a banalização da morte e a indiferença à tragédia alheia, a obra instaura, dialeticamente, um princípio emocional para reflexão sobre a Dignidade Humanaque possa se contrapor ao estigma da criminalidade cultivado no jornal como identidade coletiva.

\section{Novas aberturas dialógicas}

Com o passar do tempo, o processo de envelhecimento dos materiais do ensaio Sujeitos articulou cruzamentos temporais, diacronizando a dimensão crítica sobre os mecanismos de construção de ficções sobre a identidade popular. As diferentes curvas de envelhecimento dos materiais empregados imprimiram suas marcas no papel jornal, nas fotos, no artista. Desde então, ditaduras caíram, jornais fecharam, outros foram abertos; mas o problema da construção ficcional da identidade coletiva continua atual - o que realimentou minhas inquietações e me colocou novamente às voltas com o tema.

A forma de recepção dos ensaios fotográficos efetiva-se numa abertura de primeiro grau, enquanto poéticas da obra aberta (ECO, 1988), explorando elementos de sugestão, estranhamento e distanciamento, numa perspectiva crítica; porém, embasam-se ambos no meu ponto de vista enquanto autor sempre presente na articulação da intertextualidade mobilizada pela obra. Lembremos que o cinema, o vídeo, bem como as artes visuais, cabíveis naquela enumeração de Althusser segundo suas especificidades de linguagem, denotam consequências ideológicas e políticas na luta pelo controle das representações que

no Brasil assume significados específicos, uma vez que o controle sobre o que será representado, como e onde, está imbricado com os mecanismos de reprodução da desigualdade social. A hipótese é a de que diferentes filmes e programas de televisão, no registro da ficção e do documentário, expressam diferentes formas de 'apropriação dos mecanismos de produção da representação' (HAMBURGER, 2005: 197).

Nesse sentido, a necessidade de redimensionar a obra com novas qualidades dialógicas e polifônicas para instaurar aquela "pluralidade de vozes e de consciências independentes e distintas" de que nos fala Bakhtin (1970: 32) introduziu uma questão de ordem autoral. Variar a abertura da obra para participação em segundo grau (ECO, 1988) e interatividade em terceiro grau (PLAZA, 2003) foi o procedimento adotado para alcançar a identidade coletiva de um povo com vozque não fosse fruto exclusivo de minhas inquietações e reflexões - ou de minha "autoridade" de artista, como sublinha Couchot (apud LEÃO, 2002: 101). Desse modo, a inserção de cada espectador no exercício operativo de sua formatividade enquanto pessoa "irrepetível em sua singularidade e no entanto infinitamente aberta a possibilidades que ela mesma vai descobrir" (PAREYSON, 1993: 176) veio a contribuir com a alteridade, o dialogismo e a polifonia necessários para a 
constituição mais abrangente de um autorretrato coletivo.

A nova fase de criação desenvolveu-se em minha pesquisa criativa de Mestrado, com desdobramentos desses dois ensaios fotográficos, cujas imagens foram digitalizadas num ritual de passagem para viabilizar as novas estratégias de abertura ao espectador a serem implementadas. Dois novos núcleos foram integrados ao corpus da série:

1) núcleo de poéticas participativas, com as obras: Auto-retrato por metro quadrado; cabeça defronte; Auto-retr_ato_coletivo; Especulares \#7; Corpo coletivo; MeAndros;

2) núcleo de poéticas interativas, com as obras: AlterEgo; Doe seu rosto/Give me your face; VideoSelf e Andromaquia on-line - obra que nos interessa mais particularmente neste artigo e sobre a qual nos deteremos mais adiante.

As estratégias de abertura ao espectador nas obras do núcleo de poéticas interativas instauraram uma nova "abertura dialógica" (BAKHTIN, 1970: 340) na série Auto-retrato coletivo, mediada corporal e instantaneamente no contexto das obras em movimento (5) (TAVARES, 2000: 93-101), numa abertura de terceiro grau (PLAZA, 2003: 16-24) caracterizada por processos de interatividade viabilizados pelas NTC (Novas Tecnologias de Comunicação) ou TIC (Tecnologias da Informação e Comunicação) que instauram um novo estatuto na relação autor/obra/recepção.

Nesse novo contexto, a recuperação dos dados armazenados possibilita a escolha de elementos apresentados ao espectador de forma simultânea, que "favorece uma arte da combinatória, uma arte potencial, em que, em vez de se ter uma 'obra' acabada, tem-se apenas seus elementos e suas leis de permutação definidas por um algoritmo combinatório", de acordo com Machado (apud DOMINGUES, 1997: 145-146), que condicionam a obra à ação do espectador, sem a qual, nas palavras de Couchot, "ela continua sendo uma potencialidade não-perceptível” (apud LEÃO, 2002: 104). Evidencia-se o novo papel do receptor no contexto da interatividade, através do neologismo spect-acteur (espect-ator) de Weissberg, para quem a noção de ator "remete diretamente à noção de ato, num sentido quase gestual, por oposição à apreciação mental. E o traço de união é essencial, pois ele acopla a função perceptiva "spect” (ver) ao acabamento do ato" (1999).

Configura-se uma Poética da Ação, em que “o artista é o responsável pela idéia, pela narrativa, pelo conceito da obra, que engloba tanto a escolha dos elementos que dela tomarão parte, quanto o algoritmo combinatório, que circunscreve a seqüência de regras para o tratamento e arranjo desses elementos" (TAVARES, 2004: 4), numa mediação instantânea para exploração em tempo real. Visando à inserção do outro na recriação, o artista engendra trocas recíprocas entre o espectador e a obra, cuja atualização pressupõe que a ação do espectador esteja vinculada ao repertório do artista, "ao estoque de símbolos conhecidos e por ele atualizados que determinam sua competência e sua performance em decifrar códigos e articular 
significações" (TAVARES, 2004: 6), denotando a necessária interpretação da obra para colocar-se no papel de interator.

Pensando o dialogismo bakhtiniano no contexto interativo, observa-se uma dinâmica dialógica de repertórios com a construção de significados pelo interator, longe de uma prerrogativa autoral "monologicamente fechada" (BAKHTIN, 1998: 103). Nessa perspectiva, em coerência com Bakhtin, reitero Couchot, para quem "a obra não é mais fruto exclusivo da autoridade do artista, mas se engendra durante um diálogo em tempo real com o espectador" (apud LEÃO, 2002: 104), configurando-se um redimensionamento da presença autoral que se define pelo conceito de auteur en collectif do mesmo Weissberg, cuja reflexão privilegia uma hipertrofia da assinatura e não o seu apagamento, apontando-nos que "o contexto de hipermediação deveria acima de tudo incitar a pensar um conceito de autor em coletividade (e não de autor coletivo) que supera a recusa da individualidade em proveito de um reforço paralelo dos dois pólos” (1999).

$\mathrm{Na}$ discussão identitária de Auto-retrato coletivo, exerço meu posicionamento como esse autor em coletividade numa dinâmica com o spect-acteur à medida que "o procedimento autoral inerente à poética da ação busca despertar o envolvimento e a operação do receptor a partir de uma condição precípua, que é a de ele descobrir-se a si mesmo" (TAVARES, 2004: 9) numa perspectiva dialógica em relação à opressão e aos condicionamentos causados pelos estigmas identitários sobre grupos e individualidades.

\section{Andromaquia on-line: identidades políticas em poiesis}

O título da obra Andromaquia on-line (6) elabora um jogo de linguagem com meu nome, sugerindo, no encontro anagramático Nardo/Andro, um trânsito entre o indivíduo e o coletivo. Desdobramento da instalação participativa Cabeça defronte (2003), que propôs a pichação da parede principal do espaço como manifestação de um autorretrato coletivo, esta obra digital cria um ambiente que remete à diagramação das mídias jornalísticas, tendo como plano de fundo uma textura de papel-jornal. Nas margens laterais, as colagens digitalizadas da obra Sujeitosdispõem-se na interface da obra em estrutura hipermidiática, de modo que o interator reorganize as combinações no monitor. Aqui, instado pelo jogo permutatório, o interator pode recombinar os sentidos que definem a obra pela atualização dialógica do campo de possíveis circunscrito pelo artista. Além disso, equacionando a estrutura guttemberguiana para um "direito de resposta" on-line, convido o internauta a se expressar num campo de formulário de opinião em aberto no recorte vazado do meu autorretrato acéfalo, numa potencial "cabeça coletiva", um repositório ideológico para a polifonia a ser construída com o acréscimo das contribuições dos interatores que metaforicamente erigem uma cabeça pensante alimentada pelos diversos discursos dialógicos em confronto. O esquema de comunicação em estrela um/todos, majoritariamente praticado pelas mídias impressas, é substituído pelo esquema em espaço todos/todos do 
ciberespaço (7), aplicando em certa medida “o indispensável desvio técnico para atingir a inteligência coletiva" (LÉVY, 1999: 130) em prol da construção de uma pluralidade de discursos.

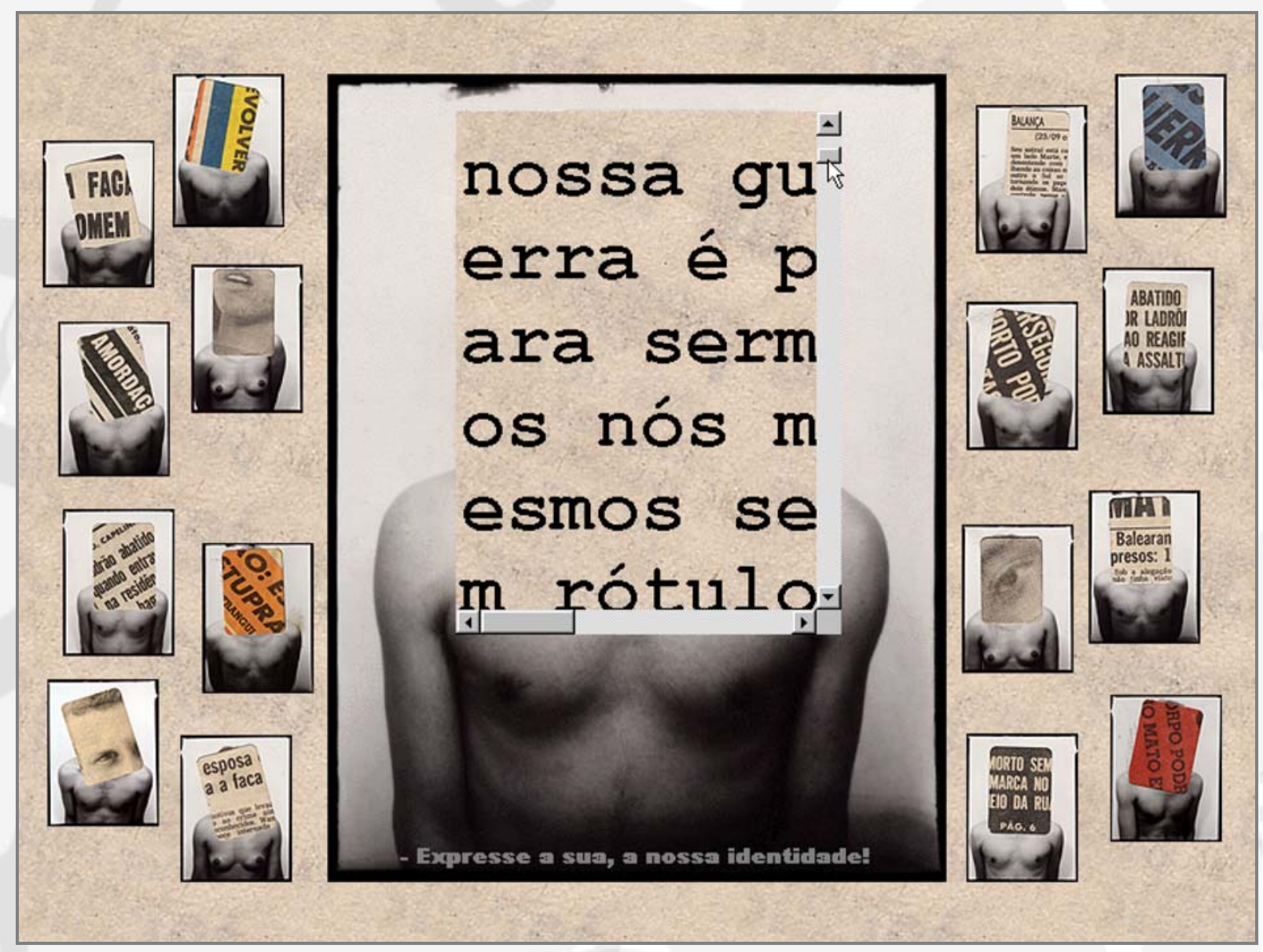

FIG. 1 -ANDROMAQUIA On-Line, 2004-2006 (Nardo Germano)

No primeiro nível da obra, a "cabeça coletiva" exibe as intervenções enviadas pelos interatores. Recordando que os graus de abertura incorporam os graus anteriores (PLAZA, 2003: 10-24), apresenta-se um contexto em que, numa abertura de primeiro grau, sob o princípio da Poética do Estranhamento de Chklovski (apud TOLEDO, 1973: 39-56), a leitura dos textos, com o deslizar da barra de rolagem, foi estabelecida seguindo o padrão da cronologia inversa de envio de dados pelos interatores - desse modo, as réplicas antecedem o discurso do outro, criando zonas de ambiguidades e descontextualizações que intentam desautomatizar e/ou aguçar a percepção. Observa-se assim uma "recepção ativa do discurso de outrem" - fator “fundamental também para o diálogo", segundo Bakhtin (1992: 146).

Além disso, na articulação desse possível diálogo entre as contribuições, destaca-se um procedimento da Poética da Sugestão, implementado "na intenção de perturbar o princípio de linearidade da linguagem" (TAVARES, 2000: 51), enfatizando o canal da mensagem: os diálogos intercalados, normalmente gerados por esse tipo de formulário, foram adotados na obra como mecanismo em potencial para "exercitar a habilidade 
decodificadora do receptor" (TAVARES, 2000: 50), na medida em que os procedimentos organizam as normas do repertório e os segmentos das perspectivas em uma sequência não-previsível, rompendo-se, assim, o "princípio da good continuation, pré-requisito dos atos diários de percepção" (ISER apud LIMA, 1979: 110) aos quais o receptor está habituado. Desse modo, destaca-se “a relevância estética dos vazios" (ISER apud LIMA, 1979: 89) que o internauta é estimulado a preencher pela interpretação (8), para compreender o encadeamento dos diálogos alternados que compõem a "cabeça coletiva”, organizando-os mentalmente.

Nesse contexto permutatório e de leitura, a Poética da Ação engendra-se de modo que "o receptor é muito mais construtor das possíveis ações do que dos sentidos possíveis da obra" (TAVARES, 2000: 100). Na reflexão de Lévy, "o ato fundamental da recepção da obra torna-se a operação", na medida em que coloca o interator numa posição em que ele "instancia uma matriz" virtual e operacional, atualizando-a a partir de sua multiplicidade pré-codificada; nessa condição, a ação e a responsabilidade do receptor na atualização da obra predominam sobre a busca de sentido da atividade hermenêutica: no campo dos possíveis da obra, "o sentido torna-se um possível, um objeto de primeira qualidade a partir de um poder de agir e decidir". Com a prioridade conferida às escolhas nesta etapa da obra, "o significado enquanto problema é que tende a desaparecer em proveito dos dilemas da ação" do interator (1998: 53-55).

Apesar de, neste momento, Andromaquia on-line propor-se como busca dos sentidos já previstos e/ou incluídos na obra, a minha expectativa é que a disposição do spect-acteur não se limite a esta etapa. Interessame, como propositor, que, ao se esgotar o campo de possíveis ou o empenho em articular repertórios e discursos alheios, sobrevenha-lhe a necessidade de se envolver com a obra num outro nível, de modo que possa incluir o seu próprio repertório e o seu próprio discurso na "cabeça coletiva" metaforicamente configurada na obra.

No segundo nível de interação, a hipermídia torna-se um fator periférico e o foco se desloca para o envio de dados a serem incorporados na obra: agora o significado como problema assume os dilemas da ação, privilegiando o potencial do ciberespaço para a constituição de sujeitos coletivos de enunciação, enquanto "produtores de sintomas políticos vivos que [permitam] aos coletivos humanos inventar e exprimir de modo contínuo enunciados complexos, abrir o leque das singularidades e das divergências, sem por isso inscrever-se em formas fixadas de antemão" (LÉVY, 2003: 67).

Nesta conversão de aisthesis para poiesis, configura-se a possibilidade de o interator inserir sua identidade na obra, na medida em que "a experiência da aisthesis pode, por fim, se incluir no processo de uma formação estética da identidade, quando o leitor faz a sua atividade estética ser acompanhada pela reflexão sobre seu próprio devir", sua própria biografia, que na ação poética do interator altera o objeto estético na “concretização de sua forma e de seu significado" (JAUSS apud LIMA, 1979: 82).

Viabilizando essa enunciação de alteridades, as soluções poéticas acessíveis ao meu interator propõemse no cruzamento do método dos limites, que privilegia o racional, e do método experimental, de tentativas e 
erros, que privilegia os sentidos (PLAZA e TAVARES, 1998: 97-103). Cabe ao interator enfrentar as regras não explicitadas na obra, entre o sensível e o inteligível, pelo espírito de descoberta e/ou pela capacidade para reconhecer estruturas. O campo do formulário (oito letras por linha, em fonte e tamanho padrões) cria condições para truncamentos e atomizações do texto, colocando elementos da Poética da Sugestão como uma das possibilidades de expressão do interator, na medida de sua capacidade de poiesis em articular esse procedimento para expressar seu pensamento. Essa possibilidade, contudo, não impede a inclusão de textos analítico-discursivos, bem como o emprego do código do teclado para composições não-verbais, livremente.

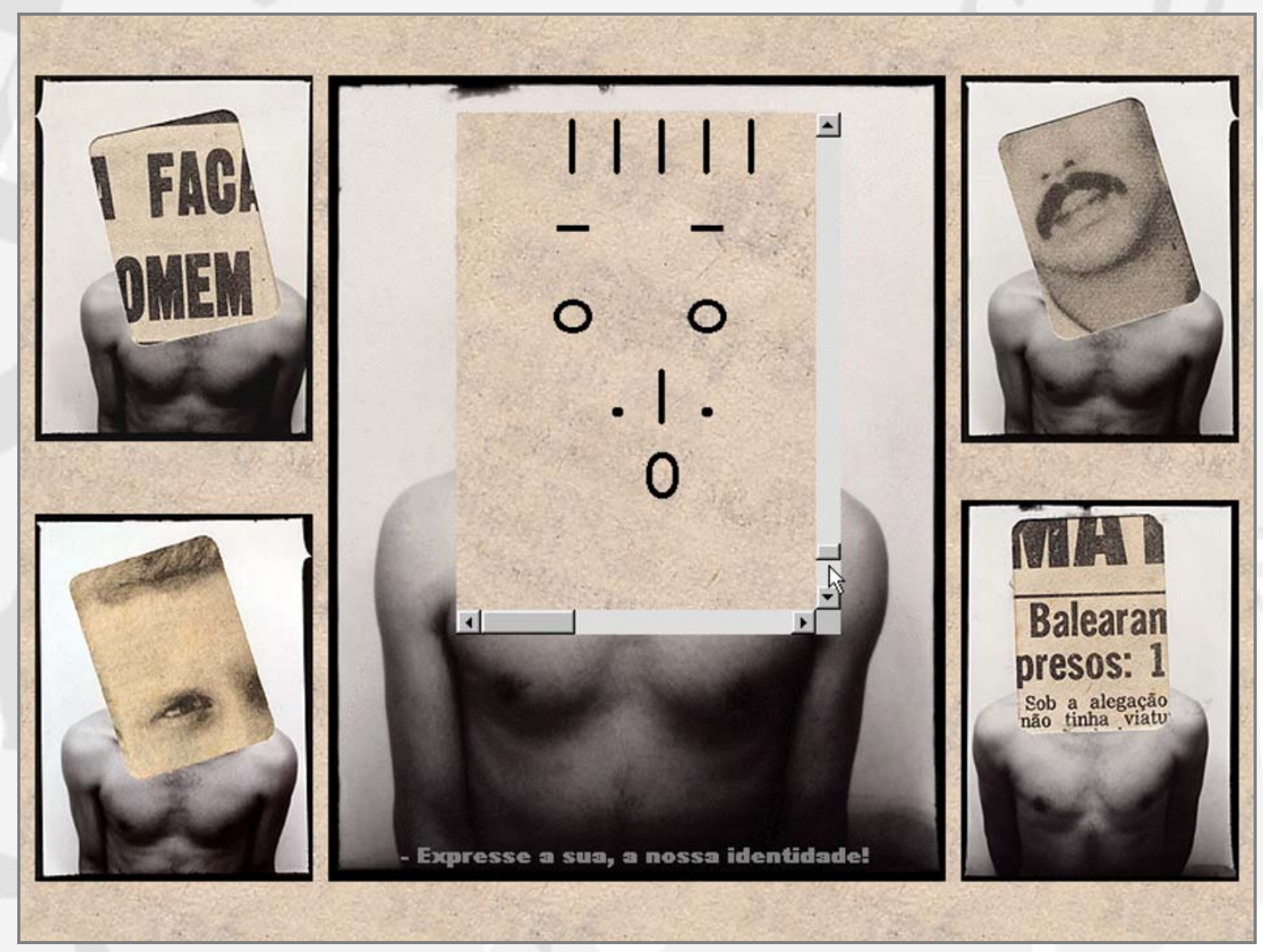

FIG. 2 -ANDROMAQUIA On-Line, 2004-2006 ( Nardo Germano)

A programação do formulário não exerce nenhum tipo de crítica ou censura sobre os dados enviados, resguardando “a autonomia e a abertura para a alteridade” (LÉVY, 1999: 132) necessárias para a representatividade do processo. Fazendo eco às palavras de Lévy, ressalto que oferecer "a uma coletividade o meio de proferir um discurso plural, sem passar por representantes, é o que está em jogo, do ponto de vista tecnopolítico" (LÉVY, 2003: 65-66), seja na proposição original de Auto-retrato coletivo, ao questionar a construção identitária fundada no discurso monológico que massifica grupos sob estigmas sociais, seja na proposição de abertura da obra ao espectador no sentido de redimensionar a minha presença autoral, para que a obra incorpore a ação do interator, sua singularidade e os elementos heteróclitos de sua contribuição, sejam 
textos, desenhos, símbolos - artísticos ou não. Estabelece-se, assim, a inclusão do ponto de vista individual na "cabeça coletiva", agregando novas significações, reforçando outras, questionando ou negando-as sem que as novas intervenções anulem as demais: não há como apagar nem "atropelar" a opinião do outro, ficando garantida assim a integridade de todas as contribuições. Nesse sentido, o interator tem a oportunidade de manifestar-se em sua individualidade, ampliando progressivamente a qualidade polifônica da obra, no mesmo espírito de abertura à alteridade que lhe foi garantido.

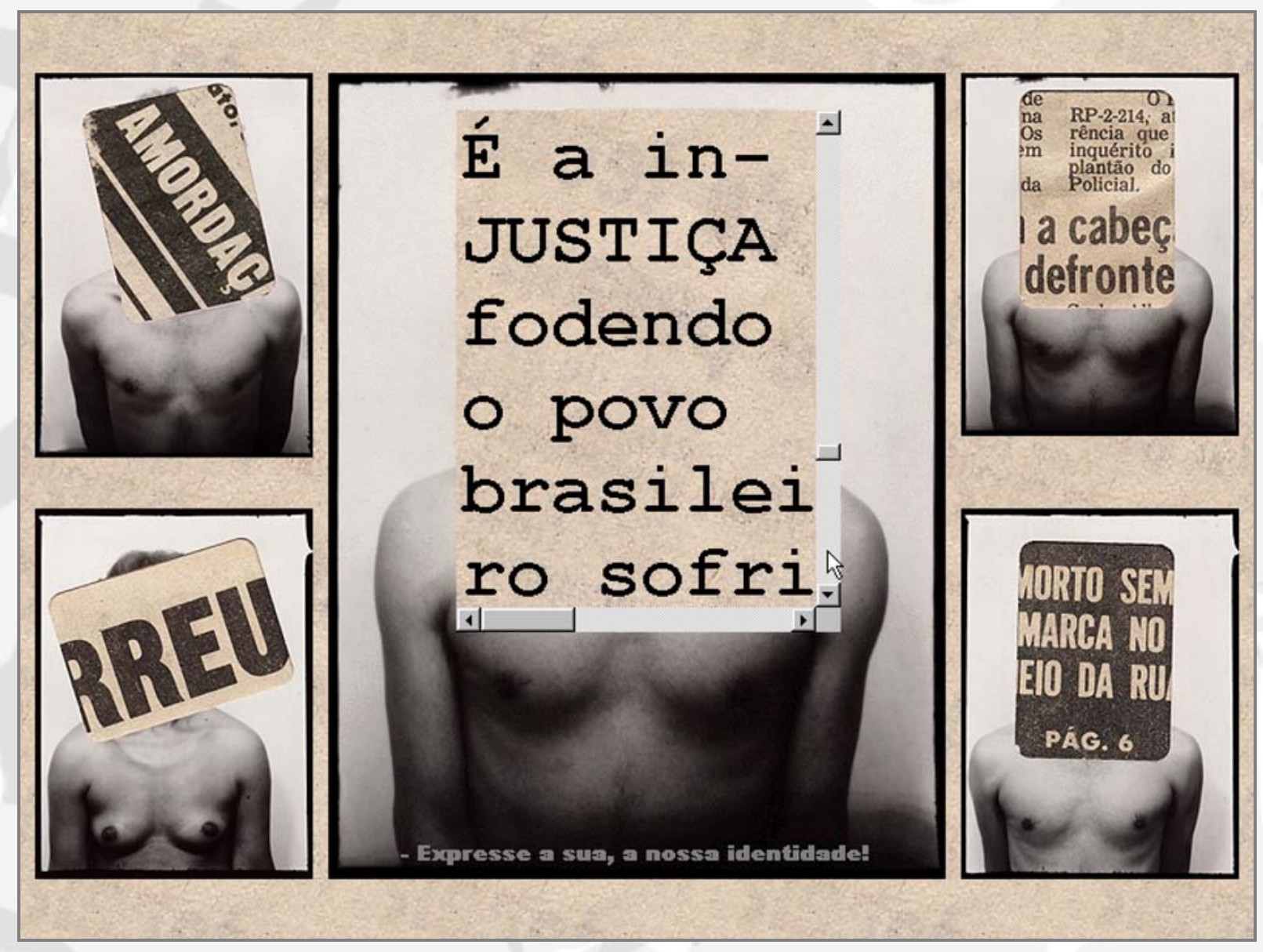

FIG.3 -ANDROMAQUIA On-Line, 2004-2006 (Nardo Germano)

Andromaquia on-line não se impõe como entidade mantenedora de um discurso monológico e consensual, mas sim provedora de um discurso hibridizado, "dialogizado interiormente" (BAKHTIN, 1998: 158): uma "cabeça coletiva" necessariamente problematizadora por sua polifonia, constituindo-se numa hibridização de discursos e linguagens, aqui correlacionada a uma das categorias básicas da linguagem narrativa elucidadas por Bakhtin, para quem a hibridização "é a mistura de duas linguagens sociais no interior de um único enunciado, é o reencontro na arena deste enunciado de duas consciências lingüísticas" (1998: 156) - ou mais (9). Nesse sentido, a modalidade de hibridização que se efetiva no processo interativo proposto constitui-se numa hibridização de pontos de vista, através das linguagens em curso. Trata-se de um híbrido que se dialogiza interiormente: os pontos de vista sócio-linguísticos não se fundem, "mas se justapõem 
dialogicamente", não conduzindo o processo "até o diálogo individual, sensato, acabado e nítido" (BAKHTIN, 1998: 158), mantendo-o sempre aberto a novas proposições e possibilidades de mudança.

Se, num primeiro nível, o reconhecimento de um repertório comum viabiliza e qualifica o espectador para o papel de interator, nesse segundo nível, o foco de meu interesse com esta obra enfatiza a inserção de repertórios trazidos do universo e da experiência de vida de cada um dos interatores em particular. A diversidade de pontos de vista e de formatividades pode assim configurar-se como identidades plurais em confronto - daí andromaquia (do grego, "combate de homens"), na perspectiva de constituição on-line de identidades políticas, num exercício colaborativo de cidadania. Nesse sentido,

\begin{abstract}
A identidade política dos cidadãos seria definida por sua contribuição à construção de uma paisagem política perpetuamente em movimento e pelo apoio que dariam a determinados problemas (...), a determinadas posições (...), a determinados argumentos (...). Com isso, cada um teria uma identidade e um papel político absolutamente singulares e diferentes dos de outro cidadão, conservando a possibilidade de concordar com os que, sobre este ou aquele assunto, em determinado momento, possuem posições próximas ou complementares (LÉVY, 2003: 65).
\end{abstract}

O instrumento dessa andromaquia não é o poder da força bruta. Propõe-se o debate como princípio fundamental bakhtiniano de dialogismo e pluralidade de vozes, que abre espaço para a coexistência das alteridades, com interpenetração e cruzamento de diferentes códigos, repertórios e discursos. A instantaneidade tecnológica instaura uma metáfora da inclusão - social e digital - do indivíduo no coletivo, utopicamente ancorada no ideal de uma inteligência coletiva que o desafia como ser pensante. O princípio em pauta é o de "reconhecer que a diversidade das atividades humanas, sem nenhuma exclusão, pode e deve ser considerada, tratada, vivida como "cultura"” (LÉVY, 1996: 120), o que redimensiona a discussão identitária numa perspectiva política: o indivíduo.

entra em contato e compõe-se com outros cérebros, com sistemas de signos, de linguagens e de tecnologias intelectuais, participa de comunidades pensantes que exploram e criam mundos múltiplos [nos quais] pluraliza sua identidade, explora mundos heterogêneos, é ele próprio heterogêneo e múltiplo, em devir, pensante (LÉVY, 2003: 135).

Traduzindo suas identidades em termos "de informação, rumo à extensão tecnológica da consciência" (McLUHAN, 1979: 23), os interatores expõem-se nos formulários de opinião, criticando e submetendo-se à crítica, numa "co-produção de sentidos" on-line (FOREST, 1998: 130), ao se apropriarem dos mecanismos de produção de suas próprias representações identitárias.

\title{
Poéticas em coletividade: identidades utópicas, identidades abertas
}

A exemplo das demais propostas interativas da série Auto-retrato coletivo, a obra Andromaquia on-line torna-se receptiva às predisposições e aos pontos de vista do público, incorporando os seus discursos como 
signos (de identidade) que compõem o próprio objeto artístico, contribuindo para o caráter polifônico de todo o corpus. Como observa Cláudia Sandoval sobre esta série, "no es más fotografía como documento o memoria, sino la imagen híbrida que permite la construcción de nuevas metáforas, de nuevas maneras de vivir la identidad, la cual se hace colectiva gracias a las nuevas tecnologías comunicacionales" (SANDOVAL, 2008) num processo de [des]construção identitária em rede.

A inclusão do espectador, de sua poética, opiniões e expressões, contribui para a expansão desse autorretrato coletivo num corpus construído em coletividade. A abertura de terceiro grau realizou-se com o concurso das Poéticas da Ação e do Jogo; somadas ao método permutatório, dos limites, às Poéticas da Sugestão, do Estranhamento etc. (recorrentes na produção das obras originais da série e incorporados no digital), são instrumentos para a elaboração de uma poiesisdos espectadores. Nesse sentido, proponho, a partir do conceito de auteur en collectif de Weissberg(1999), a noção de Poétique en collectif, ou seja, Poética em coletividade (ou Poética em coletivo, para os amantes dos galicismos). Lembrando que Pareyson (1993: 297300) grafa "Poéticas" no plural em oposição à "Estética" no singular, podemos pensar também em termos de Poéticas em coletividade ou Poéticas em coletivo, ambas no plural, reforçando a noção de dialogismo e polifonia, que é o fundamento de todo o meu projeto.
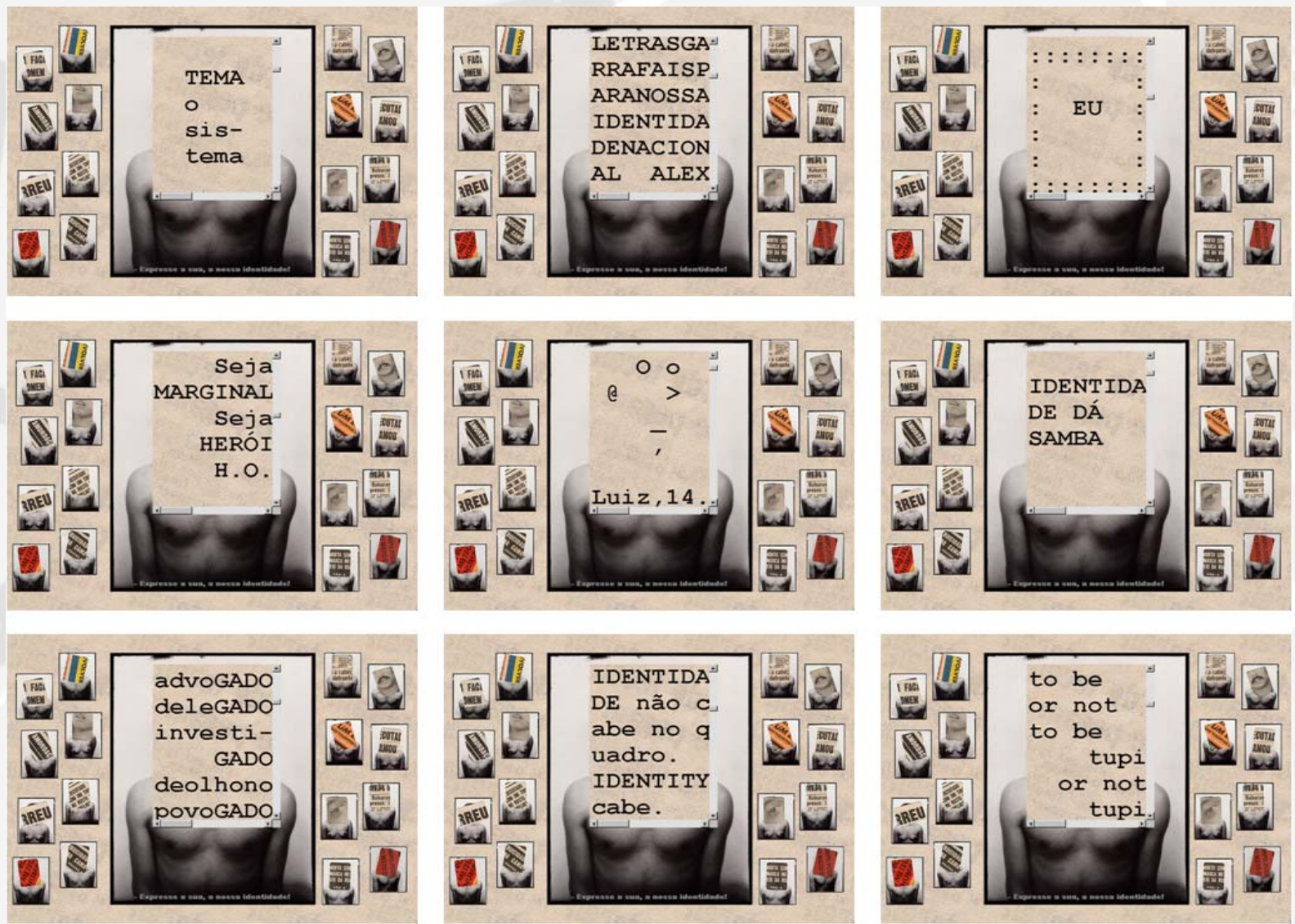

FIG.4 -ANDROMAQUIA On-Line, 2004-2006 (Nardo Germano) 
Nessa confluência de pluralidades, redimensionam-se minha presença autoral e minha poética pessoal, colocadas em coletividade. Meu autorretrato coletivo não descarta identidades nem proclama a morte do autor: há que se considerar o compromisso ético deste auteur en collectifpara empreender novas proposições nascidas das contribuições dos spect-acteurs, efetivando-as de forma autêntica ao agregar e validar poeticamente a polifonia de alteridades como exercícios de criação artística, consciência crítica e transformação.

A série propõe-se como obra transformante, em face da qual o indivíduo é instado a assumir a posição de sujeito e autor de sua própria identidade; daí a notação [autor]retrato (intervenção sobre a grafia atual da palavra, cf. o novo Acordo Ortográfico da Língua Portuguesa), que no título deste artigo salienta a autoria como primeira questão de linguagem a ser enfrentada no autorretrato. Contudo, longe da autorreferência individualista, o interator descobre-se em coletividade, num entorno relacional de alteridades com as quais dialoga.

Instaura-se uma experiência problematizadora que propõe o livre encontro de ideias e sentidos numa perspectiva dialética do ideológico e do utópico (JAMESON, 1992: 304), com a crítica negativa ideológica exercida simultaneamente com uma prática positiva como decifração de impulsos utópicos, aqui encetada com as estratégias de abertura ao espectador. Prospectivamente em aberto, o atual corpus artístico da série configura um campo amplificado de vozes, uma polifonia de pensamentos e discursos dialogizados como signos de identidades plurais, em constante movimento e transformação. Nesse sentido, Auto-retrato coletivo reelabora continuamente seu repositório crítico de uma identidade coletiva que, em sinergia com os novos procedimentos de abertura da obra à recepção, constitui-se simultaneamente como um repositório utópico de identidades abertas.

\section{NOTAS}

Este artigo apresenta reflexões de minha atual pesquisa de doutorado em Artes Visuais na ECA-USP que já foram publicadas anteriormente, em outro artigo, no $8^{\circ}$ Encontro Internacional de Arte e Tecnologia (\#8.ART): arte, tecnologia e territórios ou a metamorfose das identidades, realizado pelo Programa de Pós-Graduação em Arte do Instituto de Artes da UnB, com apoio do Museu Nacional da República. Além disso, algumas passagens deste artigo correspondem à dissertação de mestrado defendida em 2007 na ECA-USP, sobretudo aos capítulos 1 e 3, que discorrem respectivamente sobre a origem da série artística em 1987 e sobre as obras que integram o núcleo de poéticas interativas da pesquisa criativa realizada no cumprimento do projeto de abertura da obra ao espectador.

(1) Os ensaios fotográficos Auto-objeto e Sujeitos foram realizados com apoio cultural da Fotomática do Brasil, durante os encontros do Grupo de Estudos Ensaios, coordenado por Millard Schisler na Focus - Escola de Fotografia, no segundo semestre de 1987.

(2) Barthes nota que a fotografia de retratos pode ser objeto de três práticas e estabelece a distinção entre os elementos do trinômio Operator/Spectrum/Spectator, que definem respectivamente as figuras do Fotógrafo, do Fotografado e do Espectador (1981: 23-25).

(3) Embora o ensaio Auto-objetoseja composto por autorretratos e não retratos do outro, sua proposta revela mais afinidade com o conjunto de obras de artistas que explicitaram o apagamento da identidade com ênfase social e não no indivíduo, porque desenvolve uma proposta deliberada de simular a construção de uma tipologia para negá-la, numa oposição à tradição da fotografia documental identificadora de um "tipo" brasileiro. Considero essa possibilidade por 
uma correlação com a obra Brasil nativo/Brasil alienígena, de Ana Bella Geiger, cujos autorretratos paródicos recontextualizam cenas idílicas de cartões postais e que, segundo minha compreensão, se enquadram nessa via: são autorretratos cuja explicitação do "apagamento" se efetiva no âmbito social em confronto direto com a produção mistificadora e falsamente apaziguadora de uma identidade nacional.

(4) Refiro-me aqui aos retratos compósitos de Galton, a seguir claramente descritos por Fabris: "Imbuído das idéias de Lombroso, Galton decide aplicar ao campo fotográfico a teoria do 'homem médio' elaborada por Adolphe Quételet em 1835. Se o 'homem médio' do cientista belga era fruto da regularidade de incidências tomadas como evidência de determinadas leis sociais, o 'criminoso médio', de Galton, é resultado de uma abstração teórica e visual. (...) Acreditando que os criminosos partilhavam uma série de traços fisionômicos, Galton justapõe retratos de diversos indivíduos a fim de conseguir uma imagem sintética baseada nos caracteres médios do grupo por ele circunscrito. (...) $\mathrm{O}$ apagamento sucessivo dos traços fisionômicos peculiares dos diversos indivíduos que compunham as amostras fazia emergir os tipos que Galton considerava médias legítimas, verdadeiras 'estatísticas gráficas' " (2004: 47-48). As "generalizações reais" (nos termos de Galton) dos retratos compósitos entretanto conduzem a uma perigosa e inaceitável abolição das fronteiras entre o criminoso e o trabalhador das camadas inferiores da sociedade.

(5) Refiro-me à distinção de Tavares (2000: 74-101) entre participação mediada corporal, automática e instantaneamente, esta última no contexto das poéticas interativas.

(6) Autorretrato interativo (2004) inaugurado em 20 de maio na Virada Cultural SP2006, na exposição CyberArte, com obras de Regina Silveira, Carmela Gross, Julio Plaza e Agnus Valente.

(7) Lévy (2003: 63-64) aponta o esquema um/um (telefone) e um/todos (TV) em oposição ao ciberespaço, dispositivo de comunicação estruturado pelo esquema em espaço todos/todos. A comparação é igualmente válida para a imprensa, que também reproduz o esquema um/todos. Cabe ressaltar que hoje em dia jornais e revistas on-line, bem como diversos programas de TV empregam recursos tecnológicos e interativos, abrindo-se para o envio de comentários e mesmo de vídeos dos leitores e telespectadores, que são exibidos após avaliação e seleção - mas trata-se de uma adesão ainda tímida, pois a transferência dos meios de produção (da representação) demanda uma vontade política nem sempre compatível com os interesses editoriais, de mercado e de Estado (a exemplo da China, com a tentativa de instalar dispositivos de controle ao acesso na rede).

(8) Neste caso específico, não considero a inversão da ordem cronológica do envio das mensagens como criadora de "vazios" a serem preenchidos pelo interator, mas antes como instauradora de estranhamento pela descontextualização que provoca um dificultamento na recepção. Por outro lado, considero os diálogos intercalados como criadores de "vazios", e estes sim como sugestão (de acordo com Iser) enquanto "dificuldade de ideação" (apud LIMA, 1979: 112) em "oposição ao critério de dificuldade da percepção" de Chklovski (apud TOLEDO, 1973: 45).

(9) Para esclarecer esta reflexão, é necessário compreender a postura de Dostoiévski em relação ao seu herói, tal como descrito por Bakhtin: "O herói interessa a Dostoiévski, não enquanto fenômeno na realidade, possuindo traços caracterológicos e sociológicos nitidamente definidos, nem enquanto imagem determinada, composta de elementos objetivos com significação única, respondendo em seu conjunto à questão 'quem é ele?'; o herói interessa a Dostoiévski como ponto de vista particular sobre o mundo e sobre si mesmo, como a posição do homem procurando a razão de ser e o valor da realidade em torno e de sua própria pessoa." (1970: 82, tradução minha). Pensar o interator enquanto significação plural desconstrói o discurso monológico identitário, cumprindo o programa poético-político da série artística Auto-retrato coletivo.

\section{Referências bibliográficas}

ALTHUSSER, Louis. Ideologia e aparelhos ideológicos do Estado. Lisboa: Presença/Martins Fontes, 1980. BAKHTIN, Mikhail. Marxismo e filosofia da linguagem. São Paulo: Hucitec, 1992. . La poétique de Dostö̈evski. Paris: Seuil, 1970. . Questões de literatura e de estética. São Paulo: Unesp, 1998.

BARTHES, Roland. La chambre claire: note sur la photographie. Paris: Cahiers du Cinéma, Editions de l'Etoile, Gallimard, Seuil, 1980. . A câmara clara. Lisboa: Edições 70, 1981. 
BENJAMIN, Walter. Magia e técnica, arte e política. São Paulo: Brasiliense, 1987.

BERNARDET, Jean-Claude. O autor no cinema: A política dos autores: França, Brasil anos 50 e 60. São Paulo: Brasiliense/Edusp, 1994.

. Cineastas e imagens do povo. São Paulo: Companhia das Letras, 2003.

CHIARELLI, Tadeu. "Identidade/não identidade - sobre a fotografia brasileira hoje”. In: Arte Internacional Brasileira. São Paulo: Lemos-Editorial, 1999.

. O auto-retrato na (da) arte contemporânea. Campinas: Itaú Cultural, 2001.

CLARK, Lygia. Lygia Clark. Rio de Janeiro: Funarte, 1980.

COUCHOT, Edmond. A tecnologia na arte. Porto Alegre: UFRGS, 2003.

. "Sujet, objet, image”. In: Leonardo éléctronique. Cahiers Internationaux de Sociologie, vol. LXXXII, $1987 / 2001$.

DOMINGUES, Diana (org.) A arte no século XXI. São Paulo: Unesp, 1997.

ECO, Umberto. Obra aberta. São Paulo: Perspectiva, 1988. . As formas do conteúdo. São Paulo: Perspectiva/Edusp, 1974.

FABRIS, Annateresa. Identidades virtuais: uma leitura do retrato fotográfico. Belo Horizonte: UFMG, 2004.

FLUSSER, Vilém. Filosofia da caixa preta: Ensaios para uma futura filosofia da fotografia. São Paulo: Editora Hucitec, 1985.

FOREST, Fred. Pour un art actuel. Paris: L’Harmattan, 1998.

GERMANO, Nardo. Auto-retrato coletivo: Poéticas de abertura ao espectador na [des]construção de uma identidade coletiva. Dissertação de Mestrado em Artes Visuais. São Paulo, 2007.

HAMBURGER, Esther. "Políticas da representação: ficção e documentário em Ônibus 174” In: MOURÃO, Maria Dora e LABAKI, Amir (orgs.). O cinema do real. São Paulo: Cosac Naify, 2005.

JAKOBSON, Roman. Lingüistica e comunicação. São Paulo: Cultrix, 1988.

JAMESON, Fredric. O inconsciente político. São Paulo: Ática, 1992.

JAUSS, Hans Robert. Pour une esthétique de la réception. Paris: Gallimard, 1978.

LANDOW, George P. The Definition of Hypertext and Its History as a Concept. www.cyberartsweb.org/cpace/ht/jhup/history.html

LAURENTIZ, Sílvia. "Questões da imagem (2004)”. In: VALENTE, Agnus (org.). HIBRIDA Eletrônica. São Paulo, 2005 http://www.hibrida.agnusvalente.com

LEÃO, Lúcia (org). Interlab. São Paulo: Iluminuras, 2002.

LÉVY, Pierre. A inteligência coletiva: por uma antropologia do ciberespaço. São Paulo: Loyola, 2003. . O que é o virtual? São Paulo: Editora 34, 1996. . A máquina universo. Porto Alegre: Artmed, 1998. . Cibercultura. São Paulo: 34, 1999. 
LIMA, Luiz Costa (org.). A literatura e o leitor. Rio de Janeiro: Paz e Terra, 1979.

MACHADO, Arlindo. Máquina e imaginário. São Paulo: Edusp, 1993/1996.

McLUHAN, Marshall. Understanding media. São Paulo: Cultrix, 1969.

PARENTE, André. (org.) Imagem-máquina. Rio de Janeiro: 34, 1993.

PAREYSON, Luigi. Estética - Teoria da formatividade. Rio de Janeiro: Vozes, 1993.

PEIRCE, Charles Sanders. Semiótica. São Paulo: Perspectiva, 1977.

PLAZA, Julio. “Arte e interatividade: autor-obra-recepção”. In: Revista Ars, n. 2, ECA-USP. São Paulo, 2003.

PLAZA, Julio; TAVARES, Monica. Processos criativos com os meios eletrônicos: poéticas digitais. São Paulo: Hucitec, 1998.

SANDOVAL, Claudia. El debate de la fotografía y los nuevos medios de comunicación: creación colaborativa de la imagen fotográfica en el contexto brasilero. Disponível em: http://claudiasandoval.com.br/fotografiaynuevosmedios.htm

SANTAELLA, Lúcia; NÖTH, Winfried. Imagem: cognição, semiótica, mídia. São Paulo: Iluminuras, 1999.

SERRA, Antonio A. O desvio nosso de cada dia: a representação do cotidiano num jornal popular. Rio de Janeiro: Achiamé, 1980.

STARR, Paul. "The Sociology of Official Statistics”. In: ALONSO, William \& STARR, Paul. The Politics of Numbers. New York: Russels/Sage, 1983.

TAVARES, Monica. A recepção no contexto das poéticas interativas. Tese de Doutorado em Artes. São Paulo: ECA-USP, 2000.

. "O pacto de leitura das poéticas interativas”. In: Anais do XIII Encontro Anual da Compós (cdrom). São Bernardo do Campo, SP: Compós, 2004.

TOLEDO, Dionisio de Oliveira (org.). Teoria da literatura: formalistas russos. Porto Alegre: Globo, 1973.

VALENTE, Agnus. Útero portanto Cosmos: hibridações de meios, sistemas e poéticas de um sky-art interativo. Tese de Doutorado em Artes Visuais. São Paulo: ECA-USP, 2008.

WEISSBERG, Jean-Louis. Auteur, nomination individuelle et coopération productive www.info.unicaen.fr/bnum/jelec/solaris/d07/7weissberg.html

Présences à distance. Paris: L'Harmattan, 1999. www.hypermedia.univparis8.fr/Weissberg/presence/presence.htm

. "Simuler-interagir-s'hybrider = le Sujet rentre sur scene". In: THÉOFILAKIS, Elie. Modernes et après? "Les Immatériaux”. Paris: Autrement, 1985. 